\title{
Resolution of Recent Radiations Within Three Evolutionary Lineages of Felidae Using Mitochondrial Restriction Fragment Length Polymorphism Variation
}

\author{
Warren E. Johnson, ${ }^{1,4}$ Peter A. Dratch, ${ }^{2,3}$ Janice S. Martenson, ${ }^{1}$ and \\ Stephen J. O'Brien ${ }^{1}$
}

\begin{abstract}
Patterns of mitochondrial restriction fragment length polymorphism (RFLP) variation were used to resolve more recent relationships among the species of the Felidae ocelot lineage, domestic cat lineage, and pantherine lineage. Twenty-five of 28 restriction enzymes revealed site variation in at least 1 of 21 cat species. The ocelot lineage was resolved into three separate sistertaxa groups: Geoffroy's cat (Oncifelis geoffroyi) and kodkod (O. guigna), ocelot (Leopardus pardalis) and margay ( $L$. wiedii), and pampas cat (Lynchailurus colocolo) and most of the tigrina samples (Leopardus tigrina). Within the domestic cat lineage, domestic cat (Felis catus), European wild cat ( $F$. silvestris), and African wild cat $(F$. libyca) formed a monophyletic trichotomy, which was joined with sand cat $(F$. margarita) to a common ancestor. Jungle cat ( $F$. chaus) and black-footed cat ( $F$. nigripes) mtDNAs diverged earlier than those of the other domestic cat lineage species and are less closely related. Within the pantherine lineage, phylogenetic analysis identified two distinct groups, uniting lion ( $P$. leo) with leopard ( $P$. pardus) and tiger (P. tigris) with snow leopard (P. uncia).
\end{abstract}

KEY WORDS: Felidae; mitochondrial DNA; phylogenetic reconstrúction; restriction fragment length polymorphism.

\section{INTRODUCTION}

The family Felidae provides a diverse group of species with which to examine processes of evolution and resulting molecular genetic patterns. Dissimilar patterns of diversification, evolutionary history, and distribution make these species useful for characterizing genetic processes. Felid species have received a great deal of scientific and popular attention because of their charisma, important ecological roles, and conservation status due to habitat destruction and overhunting. Extensive descriptive information has accu-

\footnotetext{
'Laboratory of Viral Carcinogenesis, NCI-Frederick Cancer Research and Development Center, Frederick, Maryland 21702.

${ }^{2}$ Biological Carcinogenesis and Development Program, SAIC NCI-Frederick Cancer Research and Development Center, Frederick, Maryland 21702.

${ }^{3}$ Present address: National Fish and Wildlife Forensic Laboratory, 1490 East Main Street, Ashland, Oregon 97520.

${ }^{4}$ To whom correspondence should be addressed.
} 
mulated on their natural histories, morphology, behavior, reproduction, evolutionary history, and population genetic structure, which provides a rich basis for interpreting genetic data (Seidensticker and Lumpkin, 1991; Guggisberg, 1975; O'Brien, 1994a,b; O'Brien et al., 1996).

The 36-38 extant felid species are divided into several clades or lineages (Collier and O'Brien, 1985; O'Brien, 1986; Salles, 1992; Wozencraft, 1993). The best described of these clades are the ocelot lineage, including the ocelot (Leopardus pardalis), margay (L. wiedii), tigrina (L. tigrina), pampas cat (Lynchailurus colocolo), Geoffroy's cat (Oncifelis geoffroyi), kodkod (O. guigna), and probably Andean mountain cat (Oreailurus jacobita); the domestic cat lineage, including the domestic cat (Felis catus), African wild cat $(F$. libyca), European wild cat ( $F$. silvestris), sand cat ( $F$. margarita), blackfooted cat ( $F$. nigripes), jungle cat $(F$. chaus), and Pallas cat (Otocolobus manul); and the Panthera genus of the pantherine lineage, composed of the lion (Panthera leo), jaguar ( $P$. onca), tiger ( $P$. tigris), snow leopard ( $P$. uncia), leopard ( $P$. pardus), and possibly the clouded leopard (Neofelis nebulosa) (Wayne et al., 1989; scientific nomenclature follows Ewer, 1973). These groups were defined on the basis of comparative karyology (Wurster-Hill and Centerwall, 1982; Modi and O'Brien, 1988), the presence of two felid endogenous retroviruses in domestic cats (Benveniste and Todaro, 1974; Benveniste et al., 1975; Reeves and O'Brien, 1984), albumin immunological distance (Collier and O'Brien, 1985), allozyme electrophoresis (O'Brien et al., 1987; Pecon Slattery et al., 1994), and two-dimensional protein electrophoresis (Pecon Slattery et al., 1994).

Each of these lineages exhibits contrasting patterns of phylogeographic histories. The ancestors of the ocelot lineage, made up of small spotted cats in Central and South America (2-18 kg), probably diverged from a precursor to modern Felidae 10-12 million years ago (MYA), but evolved recently and rapidly following the formation of the Panama landbridge between North and South America (<3 MYA) (Wayne et al., 1989; Pecon Slattery et al., 1994). The domestic cat lineage diverged from the other felids more recently (8-10 MYA) and is composed of small, morphologically similar cats which have differentiated from each other over a wide area of Africa, Europe, and Asia (Guggisberg, 1975; Seidensticker and Lumpkin, 1991). The pantherine lineage includes the large and midsize cat species which diverged over the last 5-7 MY. A more recent radiation of the pantherine lineage led to the Panthera genus. These are the great cats $(15-300 \mathrm{~kg})$ with almost worldwide distribution, but which have differentiated only recently (Neff, 1982; O'Brien et al., 1987; Janczewski et al., 1995). Although these three major groups have been well supported by a variety of methods, the evolutionary associations within the lineages remain unresolved.

The present study addresses the recent phylogenetic relationships among species within each of the three major lineages using mitochondrial DNA (mtDNA) restriction fragment length polymorphisms (RFLP). MtDNA has several traits which make it useful for phylogenetic analysis, including nearly complete maternal, clonal inheritance, a general lack of recombination, and a relatively rapid rate of evolution (Avise et al., 1987; Brown, 1985; Wilson et al., 1985; Avise, 1991, 1994). RFLP analysis has the advantage of rapidly sampling the entire mitochondrial genome.

Previous research with felids using mtDNA RFLP analysis has addressed a variety of taxonomic, phylogeographic, and population level questions in selected species. 
MtDNA RFLP analysis of the endangered Florida panther subspecies ( $P$ uma concolor coryi) demonstrated genetic introgession of South American pumas into one of two extant Florida populations (O'Brien et al., 1990). In an analysis of leopards sampled from around the world, mtDNA RFLP was used (1) to determine genetic distance and divergence dates among leopard populations, (2) to demonstrate an African origin for leopards, and (3) to address subspecies classification issues (Miththapala et al., 1996). In cheetahs (Acinonyx jubatus), mtDNA RFLP was used to estimate levels of genetic variation and, combined with minisatellite data, revealed that cheetahs experienced a severe genetic bottleneck approximately 10,000 years ago (Menotti-Raymond and O'Brien, 1993). The present study provides the first comprehensive comparison of mtDNA restriction site divergence in felid species.

\section{MATERIALS AND METHODS}

Total genomic DNA was extracted, following standard methods described by Modi et al. (1987) and Sambrook et al. (1989), from frozen leukocytes, primary fibroblast cultures from skin biopsies, or frozen organs (liver, kidney, ovary) from several individuals of each of 21 felid species and a hyaenid, spotted hyena (Crocuta crocuta), which was used as the outgroup (Table I).

One microgram of DNA from each animal was digested with a panel of 28 restriction enzymes from LTI/BRL (Table II). Enzymes with more than one recognition site were chosen based on a preliminary screening. Digested samples were separated by electrophoresis on $1 \%$ agarose gels in TAE buffer $(40 \mathrm{~m} M$ Tris, $20 \mathrm{~m} M$ sodium acetate, $1 \mathrm{~m} M$ EDTA at $\mathrm{pH} \mathrm{7.2)} \mathrm{for} 16 \mathrm{hr}$ at $70 \mathrm{~V}$ and $65 \mathrm{~mA}$, then denatured, neutralized, and transferred by Southern blotting in $10 \times$ standard saline citrate (SSC) onto nylon membranes (UV Duralon, Stratagene). DNA was fixed onto membranes by UV cross-linking for $30 \mathrm{sec}$ at $120,000 \mathrm{~J}$ (Stratalinker TM $1800 \mathrm{UV}$ Crosslinker, Stratagene). Cloned domestic cat mtDNA (O'Brien et al., 1990) was randomly primed (Random Prime Kit, Boehringer-Mannheim) with $\left[^{32} \mathrm{P}\right] \mathrm{dCTP}$ (New England Nuclear) and hybridized to the membranes at $37^{\circ} \mathrm{C}$ for $16 \mathrm{hr}$ in a solution of $50 \%$ formamide, $1 \mathrm{M} \mathrm{NaCl}, 10 \mathrm{mM}$ EDTA, $50 \mathrm{~m} M$ PIPES (pH 6.4), 1\% sodium dodecyl sulfate (SDS), $5 \times$ Denhardt's solution, and $200 \mathrm{mg}$ of denatured salmon sperm DNA. Nonspecific radioactivity was removed from the membranes with three increasingly stringent SSC/SDS washes (to a final stringency of $0.2 \times$ SSC and $0.5 \%$ SDS). Membranes were blotted dry and hybridized; fragments were visualized by autoradiography (Fig. 1).

A molecular weight standard of BamHI/EcoRI digest of adenovirus II DNA (IBI) labeled with $\left[{ }^{32} \mathrm{P}\right] \mathrm{dATP}$ was used to size fragments. DNA samples from total genomic DNA and from mtDNA isolated from organ tissue on a cesium chloride gradient (Sambrook et al., 1989) were run separately for each individual of a tested species to distinguish fragments of mitochondrial sequences which may have become incorporated into the nuclear genome (Numt) of some cat species (Lopez et al., 1994).

Estimated sizes of fragments were summed for general concordance with domestic cat mitochondrial DNA, which has a length of $17 \mathrm{~kb}$, disregarding putative Numt fragments (Lopez et al., 1996). Restriction patterns (band patterns) for each enzyme were compared, and individuals were scored for presence or absence of restriction sites (frag- 
Table I. Identification Code, Sex, and Source for Each Sample (Scientific Names Follow Ewer, 1973)

\begin{tabular}{|c|c|c|c|}
\hline Species & Sample & Sex & Source \\
\hline \multicolumn{4}{|l|}{ Ocelot lineage } \\
\hline \multirow[t]{3}{*}{ Ocelot (Leopardus pardalis) } & Lpa3 & $\mathbf{M}$ & Henry Doorly Zoo, Nebraska \\
\hline & Lpa6 & $\mathbf{M}$ & Blijdorp Zoo, Netherlands \\
\hline & Lpa7 & $\mathrm{F}$ & Octagon Wildlife Park, Florida \\
\hline \multirow[t]{3}{*}{ Margay (Leopardus wiedii) } & Lwil & $\mathbf{M}$ & Carnivore Preserve Trust, North Carolina \\
\hline & Lwi8 & $\mathbf{F}$ & Blijdorp Zoo, Netherlands \\
\hline & Lwil2 & $\mathbf{F}$ & Brookfield Zoo, Illinois \\
\hline \multirow[t]{4}{*}{ Tigrina (Leopardus tigrina) } & Lti3 & $\mathbf{F}$ & Cincinnati Zoo, Ohio \\
\hline & Lti5 & $\mathrm{F}$ & P. Zool. et Botan. de Mulhouse, France \\
\hline & Lti8 & $\mathrm{U}$ & SOS Care, California \\
\hline & Lti65 & $\mathbf{M}$ & Cincinnati Zoo, Ohio \\
\hline Pampas cat (Lynchailurus colocolo) & Lco4 & $\mathrm{F}$ & Zoológico Nacional de Chile \\
\hline \multirow[t]{4}{*}{ Geoffroy's cat (Oncifelis geoffroyi) } & Oge66 & $\mathbf{M}$ & Carnivore Preserve Trust, North Carolina \\
\hline & Oge3 & $\mathbf{M}$ & Blijdorp Zoo, Netherlands \\
\hline & Oge8 & $\mathrm{F}$ & $\begin{array}{l}\text { National Zoological Park, Washington, } \\
\text { D.C. }\end{array}$ \\
\hline & Ogel1 & $\mathbf{M}$ & Washington State University \\
\hline \multirow[t]{2}{*}{ Kodkod (Oncifelis guigna) } & Ogu2 & $\mathrm{F}$ & Zoológico Nacional de Chile \\
\hline & Ogu3 & $\mathrm{F}$ & Zoológico Nacional de Chile \\
\hline \multicolumn{4}{|l|}{ Domestic cat lineage } \\
\hline Domestic cat (Felis catus) & Fca84 & $\mathrm{F}$ & NIH Animal Center, Maryland \\
\hline African wild cat (Felis libica) & Fli1 & M & Kruger Park, South Africa \\
\hline \multirow[t]{3}{*}{ European wild cat (Felis silvestris) } & Fsi7 & $\mathbf{M}$ & ISEC, Ohio \\
\hline & Fsilo & $\mathrm{F}$ & San Antonio Zoological Gardens, Texas \\
\hline & Fsi12 & $\mathrm{F}$ & Zoologischer Garten Koln, Germany \\
\hline \multirow[t]{3}{*}{ Sand cat (Felis margarita) } & Fma5 & $\mathrm{M}$ & Brookfield Zoo, Illinois \\
\hline & Fma10 & $\mathrm{M}$ & Living Desert, California \\
\hline & Fmall & $\mathbf{M}$ & Washington Park Zoo, Oregon \\
\hline \multirow[t]{3}{*}{ Black-footed cat (Felis nigripes) } & Fni3 & $\mathrm{U}$ & Meloy Laboratories, Virginia \\
\hline & Fni6 & $\mathrm{M}$ & San Diego Zoo, California \\
\hline & Fni7 & $\mathrm{F}$ & San Diego Zoo, California \\
\hline \multirow[t]{2}{*}{ Jungle cat (Felis chaus) } & Fch2 & $\mathbf{M}$ & Blijdorp Zoo, Netherlands \\
\hline & Fch4 & $\mathrm{U}$ & Meloy Laboratories, Virginia \\
\hline \multirow[t]{2}{*}{ Pallas cat (Otocolobus manul) } & Oma4 & $F$ & Baltimore Zoo, Maryland \\
\hline & Oma10 & $\mathrm{F}$ & Brookfield Zoo, Illinois \\
\hline \multicolumn{4}{|l|}{ Pantherine lineage } \\
\hline \multirow[t]{5}{*}{ Leopard (Panthera pardus) } & Ppa5 & $\mathbf{F}$ & Henry Doorly Zoo, Nebraska \\
\hline & Ppa6 & $\mathrm{F}$ & Henry Doorly Zoo, Nebraska \\
\hline & Ppa20 & $\mathrm{U}$ & Minnesota Zoological Gardens \\
\hline & Ppa21 & $\mathrm{U}$ & Minnesota Zoological Gardens \\
\hline & Ppa30 & $\mathrm{F}$ & Lincoln Park Zoo, Illinois \\
\hline \multirow[t]{5}{*}{ Lion (Panthera leo) } & Ple7 & $\mathrm{F}$ & National Zoological Park, Wash. D.C. \\
\hline & Ple13 & $\mathbf{M}$ & National Zoological Park, Wash. D.C. \\
\hline & Ple23 & M & Wildlife Safari Park, Oregon \\
\hline & $\mathrm{Ple} 24$ & $\mathbf{F}$ & National Zoological Park, Wash. D.C. \\
\hline & Ple105 & $\mathbf{U}$ & Woodland Park Zoo, Washington \\
\hline \multirow[t]{2}{*}{ Jaguar (Panthera onca) } & Pon1 & $\mathrm{F}$ & Carnivore Preserve Trust, North Carolina \\
\hline & Pon9 & U & Johannesburg Zool. Garden, S. Africa \\
\hline \multirow[t]{3}{*}{ Snow leopard (Panthera uncia) } & Pun4 & $\mathbf{M}$ & Detroit Zoo, Michigan \\
\hline & Pun9 & $\mathbf{M}$ & Calgary Zoo-Botanical Garden, Canada \\
\hline & Pun10 & $\mathrm{F}$ & New York Zoological Park \\
\hline \multirow[t]{7}{*}{ Tiger (Panthera tigris) } & Pti2 & $\mathrm{M}$ & Carnivore Preserve Trust, North Carolina \\
\hline & Pti48 & $\mathbf{M}$ & Minnesota Zoological Garden \\
\hline & Pti65 & $\mathbf{M}$ & Philadelphia Zool. Garden, Pennsylvania \\
\hline & Pti66 & $\mathbf{F}$ & Stone Zoo, Massachusetts \\
\hline & Pti69 & $\mathbf{M}$ & New York Zoological Park \\
\hline & Pti76 & $\mathbf{M}$ & Rare Feline Breeding Colony, California \\
\hline & Pti77 & $\mathrm{M}$ & Knoxville Zoological Park, Tennessee \\
\hline
\end{tabular}


Table I. Continued

\begin{tabular}{llll}
\hline \multicolumn{1}{c}{ Species } & Sample & Sex & \multicolumn{1}{c}{ Source } \\
\hline & Pti81 & F & San Diego Zoo, California \\
& Pti82 & M & San Diego Zoo, California \\
& Pti83 & F & San Diego Zoo, California \\
Clouded leopard (Neofelis nebulosa) & Nne9 & F & National Zoological Park, Wash. D.C. \\
& Nne19 & F & Minnesota Zoological Garden \\
& Nne22 & F & NZP/Conservation Research Center, \\
Jaguarundi (Herpailurus yagouaroundi) & Hya8 & M & San Diego Zoo, California \\
Cheetah (Acinonyx jubatus) & Aju70 & F & St. Louis Zoological Park, Illinois \\
& Aju96 & F & Wildlife Safari, Oregon \\
& Aju227 & U & Nairobi Orphanage, Kenya \\
Outgroup & Aju254 & M & St. Louis Zoological Park \\
Spotted hycna (Crocuta crocuta) & Ccr2 & F & Henry Doorly Zoo, Nebraska \\
\hline
\end{tabular}

Table II. Polymorphic Restriction Enzymes Within Felid Species ${ }^{a}$

\begin{tabular}{|c|c|c|c|c|}
\hline Species & Code & $\begin{array}{l}\text { Sample } \\
\text { size }\end{array}$ & $\begin{array}{l}\text { Number of } \\
\text { haplotypes }\end{array}$ & Polymorphic restriction enzymes \\
\hline Leopardus pardalis & Lpa & 3 & 3 & $\begin{array}{l}\text { AccI, Aval, AvaII, BclI, ClaI, Hind III, } \\
\text { NdeI, StuI , XbaI }\end{array}$ \\
\hline Leopardus wiedii & Lwi & 3 & 3 & $\begin{array}{l}\text { AvaI, AvaII, BamHi, BclI, EcoRI, } \\
\text { HincII, HindIII, HpaI, NcoI, NdeI, } \\
\text { SstI }\end{array}$ \\
\hline Leopardus tigrina & Lti & 4 & 4 & $\begin{array}{l}\text { AccI, AvaI, AvaII, BamHI, BglI, } \\
\text { BstUI, BstEII, ClaI, DRaI, EcoRI, } \\
\text { EcoRV, HincII, HindIII, HpaI, } \\
\text { NcoI, NdeI, StuI, XbaI }\end{array}$ \\
\hline Oncifelis geoffroyi & Oge & 4 & 4 & $\begin{array}{l}\text { AccI, ApaI, AvaII, BglII, BstUI, } \\
\quad \text { BstEII, ClaI, DraI, NdeI, SstI, StuI }\end{array}$ \\
\hline Oncifelis guigna & Ogu & 2 & 2 & ApaI, Ncol \\
\hline Felis silyestris & Fsi & 3 & 3 & $\begin{array}{l}\text { ApaI, AvaI, AvaII, BamHI, BclI, BglI, } \\
\text { BstUI, ClaI, EcoRI, NcoI, NdeI, } \\
\text { SmaI, SstI, XbaI }\end{array}$ \\
\hline Felis margarita & Fma & 3 & 1 & \\
\hline Felis nigripes & Fni & 3 & 2 & $\begin{array}{l}\text { ApaI, AvaI, AvaII, BstEII, ClaI, NcoI, } \\
\text { SmaI, SstI, XbaI }\end{array}$ \\
\hline Felis chaus & Fch & 2 & 1 & \\
\hline Otocolobus manul & Oma & 2 & 1 & \\
\hline Panthera pardus & Ppa & 5 & 4 & $\begin{array}{l}\text { AvaII, AvaI*, Bst } \mathrm{UI}^{*}, C l a \mathrm{I}^{*}, E c o \mathrm{RV}^{*} \\
\text { HincII*, HindII', HpaI**, NcoI, } \\
\text { PstI, XbaI }\end{array}$ \\
\hline Panthera leo & Ple & 5 & 3 & $A v a I^{*}, B a m \mathrm{HI}{ }^{*}, B g l I^{*}, P_{s t I}$ \\
\hline Panthera onca & Pon & 2 & 2 & $\begin{array}{l}\text { AvaII, Bst UI, DraI, HindIII, KpnI, } \\
\quad \text { NcoI, SstI }\end{array}$ \\
\hline Panthera uncia & Pun & 3 & 2 & EcoRV \\
\hline Panthera tigris & Pti & 10 & 1 & \\
\hline Neofelis nebulosa & Nne & 3 & 1 & \\
\hline Acinonyx jubatus & Aju & 4 & 1 & \\
\hline
\end{tabular}

${ }^{a}$ Asterisks refer to restriction enzymes known to be polymorphic in this species from other studies. Cheetahs (A. jubatus) and tigers (P. tigris) were monomorphic for all 28 restriction enzymes. 


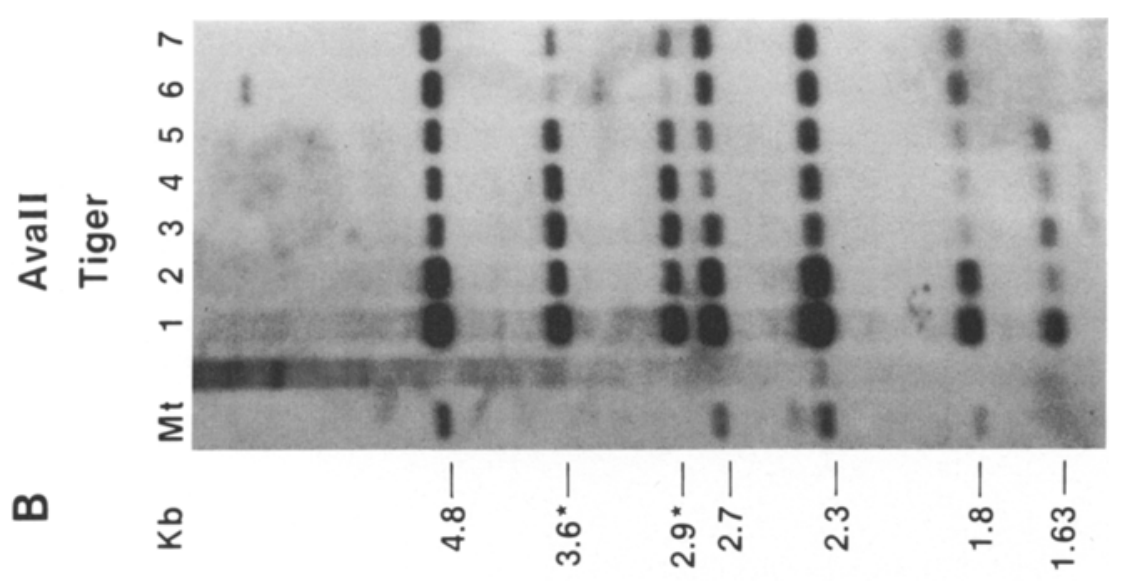

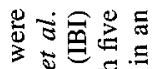

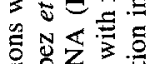
总吅员里 焉宁台豆 东里包

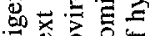

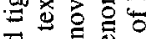

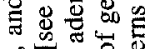

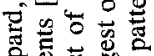

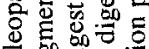
政.

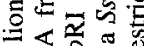
느요

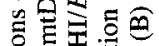
递要过


영 क्षे

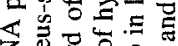

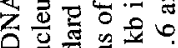
㩆焉的

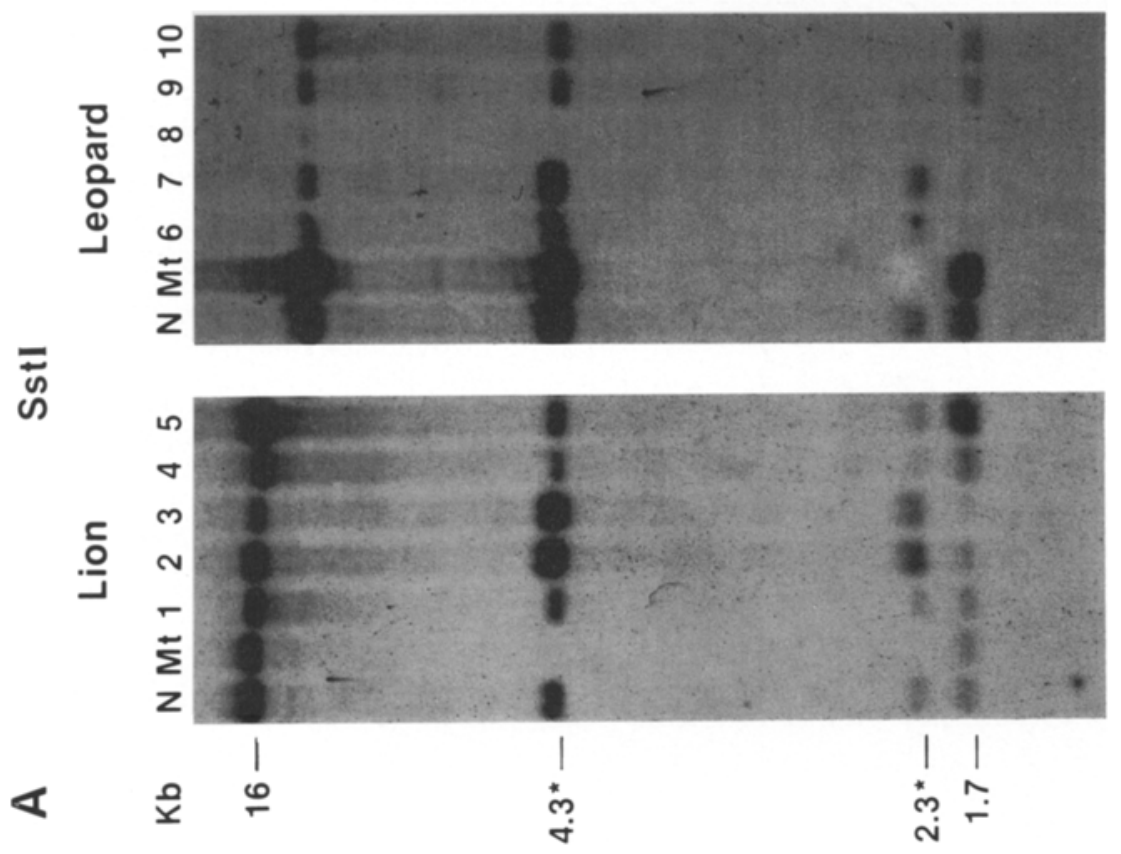

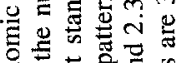

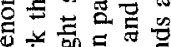

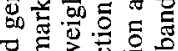
进药

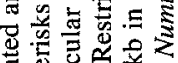
要递安的 过西



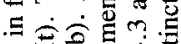

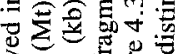
的焉

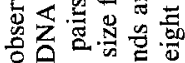

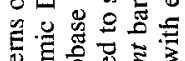

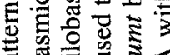

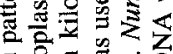

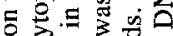

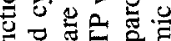
믈 능 昰记送

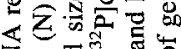

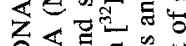

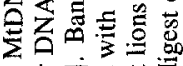

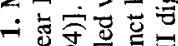

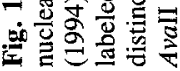


ments of equal sizes). Individual haplotypes were compiled from patterns of restriction sites across all the enzymes.

To facilitate comparison of shared fragments for each enzyme, all individuals of the ocelot lineage were run on one gel and all individuals of the domestic cat lineage were run on a separate gel. Due to the number of individuals tested, two gels were needed for the individuals of the pantherine lineage, with the same five individuals used on both gels to allow band comparisons between gels. For each lineage, the spotted hyena was used as a nonfelid outgroup species, along with at least one felid from outside the lineage represented on the gel. Band sharing and phylogenetic analyses were restricted to species samples compared on a single gel.

Percentage interspecies variation (p) was estimated using Nei and Li's (1979) index of proportion of fragments shared, or of equal size $(\tau=$ pi), computed by FRAG-NEW (developed by J. Avise and M. Ball and modified for larger data sets). This is the equivalent of $d_{x y}$ of the RESTML algorithm of PHYLIP. For maximum-parsimony analysis the presence or absence of fragments were used as characters.

Phylogenetic relationships among individuals within each set of RFLP data were constructed from the distance data by the minimum-evolution method estimated by the neighbor-joining algorithm of the PHYLIP computer package (Version 3.5) (Felsenstein, 1993) and from the character data using the Dollo parsimony model with the heuristic option of PAUP (Version 3.1.1) (Swofford, 1993), followed by the bootstrapping option with 100 resamplings. Dollo parsimony (Farris, 1977) was used because parsimony analysis of restriction-site data may be reliable only when divergences are less than 1\% (Nei and Tajima, 1985) and because it is more likely that an existing restriction site will be lost than gained at any particular location (Templeton, 1983; DeBry and Slade, 1985). Dollo parsimony assumes that each character state evolves only once (gains of the derived condition in parallel branches are not permitted) and that all homoplasy is due to a reversal to a more ancestral condition (Swofford, 1993). For comparison, trees were also constructed by maximum parsimony using the heuristic option of PAUP (Version 3.1.1) (Swofford, 1993).

\section{RESULTS}

Mitochondrial DNA variation of the three major lineages of Felidae (ocelot, domestic cat, and pantherine lineage) was characterized by RFLP analyses using 28 restriction enzymes. Within the pantherine lineage, 429 restriction sites were scored for 38 individuals of 11 species, representing 2456 nucleotides, or $14.4 \%$ of the $17,000 \mathrm{bp}$ in the feline mitochondrial DNA (Lopez et al., 1996). For the domestic cat lineage, 423 restriction sites were scored based on 21 individuals of 12 species representing 2438 nucleotides (14.3\% of the mtDNA). With the ocelot lineage, 402 restriction sites were scored for 25 individuals of 13 species, representing 2279 nucleotides (13.4\% of the mtDNA).

Twenty-five of 28 restriction enzymes demonstrated intraspecies polymorphism in at least 1 of 17 felid species tested with more than one individual (Tables II and III). Tigrina had multiple banding patterns for the largest number of enzymes (18 of 23), followed by European wild cat (14 of 25) and by margay and Geoffroy's cat (11 of 23). In contrast, no polymorphic sites were detected in the 10 tigers or 4 cheetahs tested. 
Table III. The Occurrence of Nuclear Mitochondrial (Numt) Fragments in Tested Species ${ }^{a}$

\begin{tabular}{|c|c|c|c|c|c|c|c|c|c|c|}
\hline & $\begin{array}{c}A c c \mathrm{I} \\
4\end{array}$ & $\begin{array}{c}\text { ApaI } \\
3\end{array}$ & $\begin{array}{c}\text { AvaI } \\
3\end{array}$ & $\begin{array}{c}\text { AvalI } \\
7\end{array}$ & $\begin{array}{c}\text { BamHI } \\
2\end{array}$ & $\begin{array}{c}B c I I \\
3\end{array}$ & $\begin{array}{c}B g l \mathbf{I} \\
0\end{array}$ & $\begin{array}{c}\text { BglII } \\
0\end{array}$ & $\begin{array}{c}B s t \mathrm{UI} \\
3\end{array}$ & $\begin{array}{c}\text { BstEII } \\
2\end{array}$ \\
\hline Lpa & - & - & - & - & - & - & - & - & - & - \\
\hline Lwi & - & - & - & - & 一 & - & - & - & - & - \\
\hline Lti & - & - & - & - & - & - & - & - & - & - \\
\hline Oge & - & - & - & - & - & - & - & - & - & - \\
\hline Ogu & - & - & - & - & - & - & - & - & - & - \\
\hline Fca & $2(7.2)$ & $2(3.4)$ & - & - & $1(7.4)$ & $2(6.7)$ & $1(8.0)$ & ND & - & $2(8.0)$ \\
\hline Fli & $5(11.5)$ & $2(3.2)$ & - & $3(6.2)$ & $1(7.4)$ & - & - & ND & - & $2(7.5)$ \\
\hline Fsi & $2(7.2)$ & $2(3.2)$ & - & $2(5.2)$ & $1(7.4)$ & $2(6.7)$ & - & ND & - & $2(7.5)$ \\
\hline Fma & $1(7.5)$ & $2(7.4)$ & - & $2(4.2)$ & $1(7.4)$ & $2(6.7)$ & - & ND & - & - \\
\hline Fch & - & - & - & - & - & - & - & ND & - & - \\
\hline Fni & - & - & - & - & - & - & - & ND & - & - \\
\hline Oma & - & - & - & - & - & - & - & ND & - & - \\
\hline Ppa & ND & - & - & $1(7.6)$ & $2(6.4)$ & - & $3(6.0)$ & ND & - & - \\
\hline Ple & ND & $2(5.7)$ & $1(7.8)$ & $1(8.6)$ & $2(6.8)$ & $3(2.2)$ & $1(3.6)$ & ND & - & $1(4.7)$ \\
\hline Pon & ND & - & $1(14.8)$ & - & $1(3.6)$ & - & $2(3.5)$ & ND & - & $1(4.7)$ \\
\hline Pun & ND & $2(9.7)$ & $3(44.0)$ & $1(2.2)$ & - & - & - & ND & - & - \\
\hline Pti & ND & $2(16.2)$ & $2(32.6)$ & $2(6.5)$ & $3(17.4)$ & - & $2(3.4)$ & ND & - & $1(2.7)$ \\
\hline Nne & ND & - & - & - & - & - & - & ND & - & - \\
\hline Hya & - & - & - & - & - & ND & - & - & - & - \\
\hline \multirow[t]{2}{*}{ Aju } & ND & - & - & - & - & - & - & ND & - & - \\
\hline & $\begin{array}{c}\text { ClaI } \\
3\end{array}$ & $\begin{array}{c}\text { DraI } \\
5\end{array}$ & $\begin{array}{c}\text { EcoRI } \\
1\end{array}$ & $\begin{array}{c}E_{c o R V} \\
1\end{array}$ & $\begin{array}{c}\text { HincII } \\
10\end{array}$ & $\begin{array}{c}\text { HindIII } \\
4\end{array}$ & $\begin{array}{c}\text { HapI } \\
6\end{array}$ & $\begin{array}{c}\text { KpnI } \\
0\end{array}$ & $\begin{array}{c}\text { Ncol } \\
2\end{array}$ & $\begin{array}{c}N d e \mathrm{I} \\
1\end{array}$ \\
\hline Lpa & - & - & - & - & - & - & - & ND & - & - \\
\hline Lwi & - & - & - & - & - & - & - & ND & - & - \\
\hline Lti & - & - & - & - & - & - & - & ND & - & - \\
\hline Oge & - & - & - & - & - & - & - & ND & - & - \\
\hline Ogu & - & - & - & - & - & - & - & ND & - & - \\
\hline Fca & - & $2(3.0)$ & $1(7.6)$ & $1(8.1)$ & $1(2.6)$ & - & - & ND & $2(9.1)$ & - \\
\hline Fli & - & $2(3.0)$ & $1(7.6)$ & $1(8.1)$ & $2(6.0)$ & - & - & ND & $3(11.6)$ & - \\
\hline Fsi & - & $2(3.0)$ & $1(7.6)$ & $1(8.1)$ & $1(2.6)$ & - & - & ND & $2(9.1)$ & - \\
\hline Fma & - & $1(1.8)$ & - & - & $1(2.6)$ & - & - & ND & $1(1.6)$ & - \\
\hline Fch & - & $1(1.8)$ & $1(7.6)$ & - & - & - & - & ND & $2(9.1)$ & - \\
\hline Fni & - & - & - & - & - & - & - & ND & - & - \\
\hline Oma & - & - & - & - & - & - & - & ND & - & - \\
\hline Ppa & - & $1(2.1)$ & $1(8.6)$ & - & - & $1(8.1)$ & $1(3.6)$ & $1(7.9)$ & - & ND \\
\hline Ple & - & $1(2.0)$ & $1(8.6)$ & - & - & $2(7.2)$ & $1(3.6)$ & $1(7.9)$ & - & ND \\
\hline Pon & - & - & - & - & - & - & - & $1(7.9)$ & - & ND \\
\hline Pun & $1(5.0)$ & $1(2.9)$ & - & - & $1(8.9)$ & $1(7.3)$ & $1(8.6)$ & - & $2(10.8)$ & ND \\
\hline Pti & $1(5.0)$ & $6(12.6)$ & - & - & $1(2.8)$ & - & $1(8.6)$ & - & $3(6.2)$ & ND \\
\hline Nne & - & - & - & - & - & - & - & - & - & ND \\
\hline Hya & - & - & - & - & - & 一 & - & ND & - & - \\
\hline \multirow[t]{3}{*}{ Aju } & - & - & - & - & - & - & - & - & - & ND \\
\hline & \multirow{2}{*}{$\begin{array}{c}P_{s f} \mathbf{I} \\
0\end{array}$} & \multicolumn{2}{|c|}{ PvuII } & SalI & Sstl & SstII & \multicolumn{2}{|c|}{ Stul } & $X b a \mathbf{I}$ & Xhol \\
\hline & & \multicolumn{2}{|c|}{0} & 0 & 1 & 2 & \multicolumn{2}{|c|}{5} & 4 & 0 \\
\hline Lpa & ND & \multicolumn{2}{|c|}{ ND } & ND & - & - & \multicolumn{2}{|l|}{-} & - & ND \\
\hline Lwi & ND & & ND & ND & - & - & \multicolumn{2}{|l|}{-} & - & ND \\
\hline Lti & ND & & ND & ND & - & - & \multicolumn{2}{|l|}{-} & - & ND \\
\hline Oge & ND & & ND & ND & - & - & \multicolumn{2}{|l|}{ - } & - & ND \\
\hline Ogu & ND & & ND & ND & - & - & \multicolumn{2}{|l|}{-} & - & $\Rightarrow N D$ \\
\hline Fca & - & & - & ND & $1(5.6)$ & - & \multicolumn{2}{|c|}{$1(2.2)$} & - & ND \\
\hline Fli & - & & - & ND & $1(5.6)$ & - & \multicolumn{2}{|c|}{$1(2.2)$} & - & ND \\
\hline Fsi & - & & - & $\mathrm{ND}$ & $1(5.6)$ & - & \multicolumn{2}{|c|}{$1(2.2)$} & - & ND \\
\hline
\end{tabular}


Table III. Continued

\begin{tabular}{lcccccccc}
\hline & $P s t \mathrm{I}$ & PvuII & SalI & SstI & SstII & StuI & XbaI & $\begin{array}{c}\text { XhoI } \\
\end{array}$ \\
& 0 & 0 & 0 & 1 & 2 & 5 & 4 & 0 \\
\hline Fma & - & - & ND & $1(5.6)$ & - & - & - & ND \\
Fch & - & - & ND & $1(5.6)$ & - & - & - & ND \\
Fni & - & - & ND & - & - & - & - & ND \\
Oma & - & - & ND & - & - & - & - & ND \\
Ppa & $1(4.5)$ & $1(8.3)$ & - & $1(2.3)$ & - & ND & $1(4.7)$ & - \\
Ple & $2(8.4)$ & $1(8.3)$ & $1(8.4)$ & $2(6.6)$ & - & ND & $4(8.4)$ & - \\
Pon & $1(4.5)$ & - & - & $2(6.6)$ & - & ND & - & - \\
Pun & $2(12.8)$ & - & - & $4(16.9)$ & - & ND & $1(4.7)$ & - \\
Pti & $1(9.3)$ & $1(12.0)$ & - & $4(11.2)$ & - & ND & $3(16.0)$ & - \\
Nne & - & - & - & - & - & ND & - & - \\
Hya & - & ND & ND & - & - & - & - & ND \\
Aju & - & - & - & - & - & - & - & - \\
\hline
\end{tabular}

${ }^{a}$ Below the restriction enzyme is the number of restriction sites in the domestic cat Numt sequence (Lopez et al., 1994). The number of fragments in each species (codes from Table II) is followed, in parentheses, by the total $\mathrm{kb}$ size of the Numt fragment(s). (-) No Numt sequences were observed in this species' restriction enzyme combination. ND refers to enzymes which were not tested with this species.

Mitochondrial DNA evolution in the Felidae is somewhat complicated by the occurrence of Numt, an ancient tandem amplification of $7.9 \mathrm{~kb}$ of mtDNA located on nuclear chromosome D2 in domestic cats and also in closely related species (Lopez et al., 1994). Because of the high copy number (38-56x) of Numt present in nuclear DNA, Southern blot fragments in species with Numt consist of both cytoplasmic mtDNA and nuclear Numt fragments. To discriminate between Numt and cytoplasmic mtDNA in the present study, purified cytoplasmic (nonnuclear) DNA preparations were compared to wholecell DNA preparations to identify species with Numt fragments (Fig. 1). Ten species displayed Numt specific nuclear RFLP signals (Fig. 1 and Table III), five from the domestic cat lineage ( $F$. catus, $F$. silvestris, $F$. libyca, $F$. margarita, and $F$. chaus) and five from species of the genus Panthera ( $P$. tigris, $P$. leo, $P$. pardus, $P$. onca, and $P$. uncia). Because these species represent monophyletic lineages within the felid radiation, it is likely that Numt amplification across two disparate lineages represents two unique evolutionary events. Numt fragments were not considered for construction of phylogenetic relationships.

Pairwise percentage interspecies variation $(p)$ (Nei and $\mathrm{Li}, 1979$ ) varied from 1 to $19 \%$ among all cats, including outgroup species (Tables IV-VI). Interspecies variation reached $16 \%$ within the pantherine lineage (between leopard and snow leopard), $12 \%$ within the ocelot lineage (between some individuals of Geoffroy's cat and margay), and 7\% within the domestic cat lineage (between Pallas cat and black-footed cat).

\section{Ocelot Lineage}

Phylogenetic analysis of mtDNA from species of the ocelot lineage revealed three groups which were well supported by distance based and Dollo parsimony methods (Figs. 2A and B). These groups, composed of Geoffroy's cat (Oge) and kodkod (Ogu), ocelot (Lpa) and margay (Lwi), and pampas cat (Lco) and three of the tigrinas (Lti), had boot- 


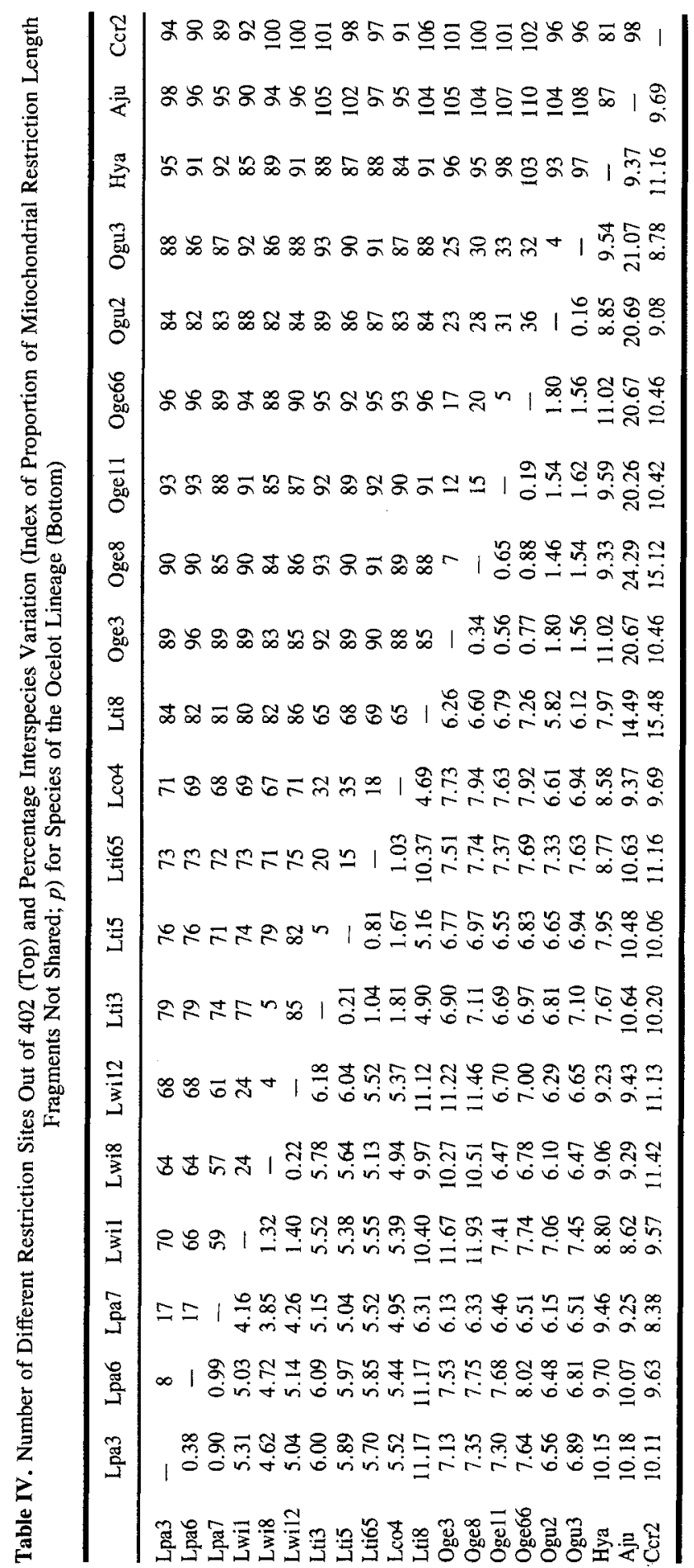




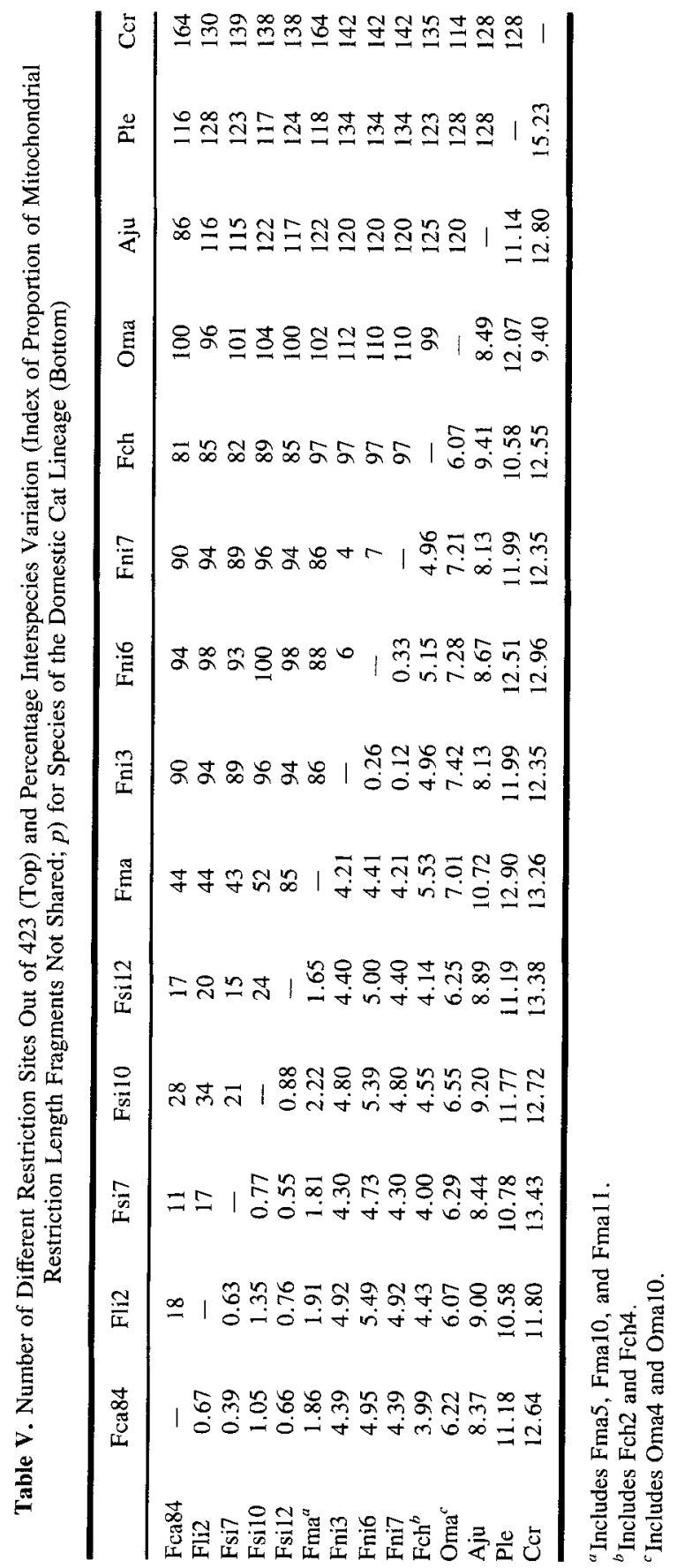




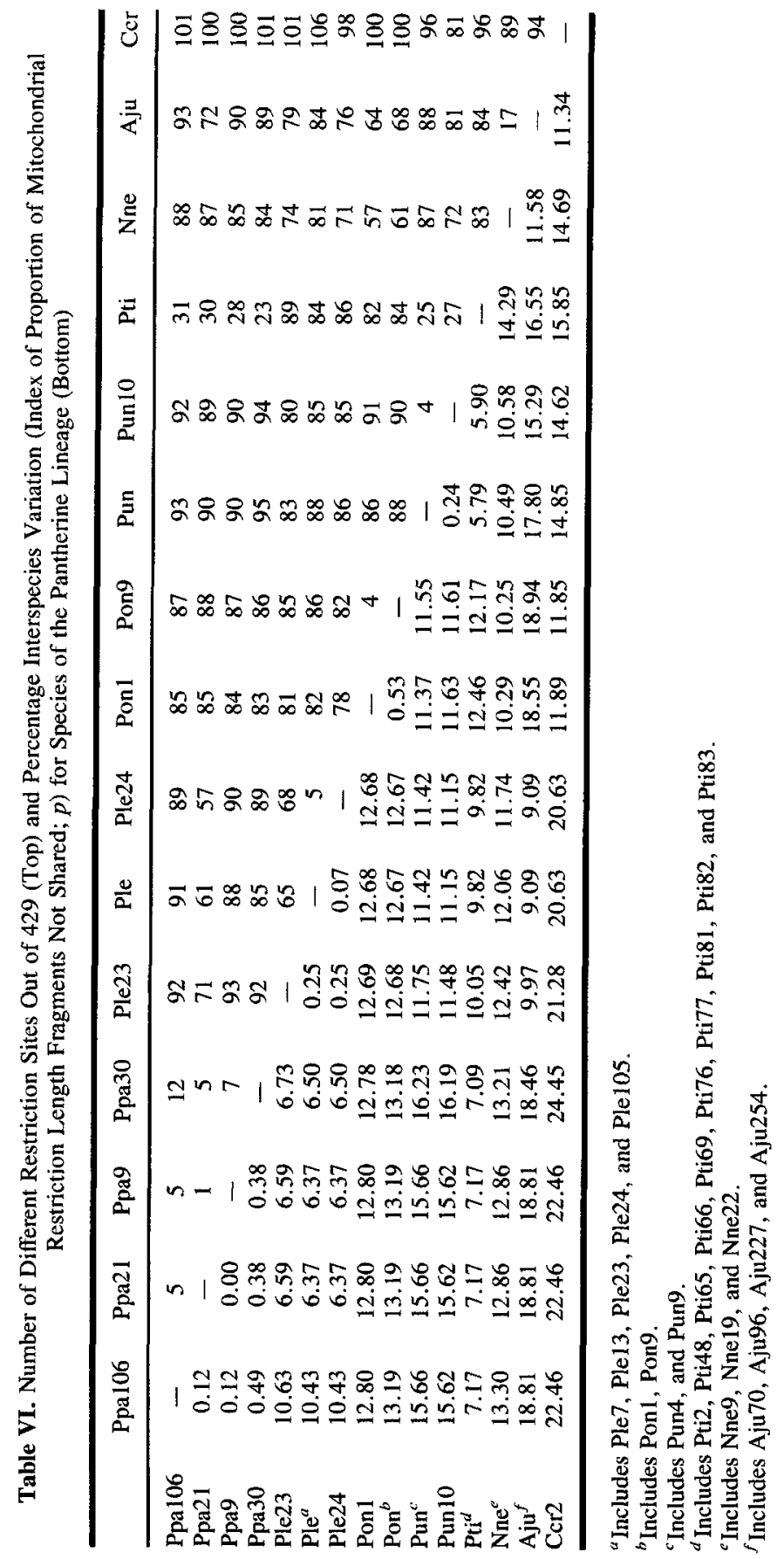



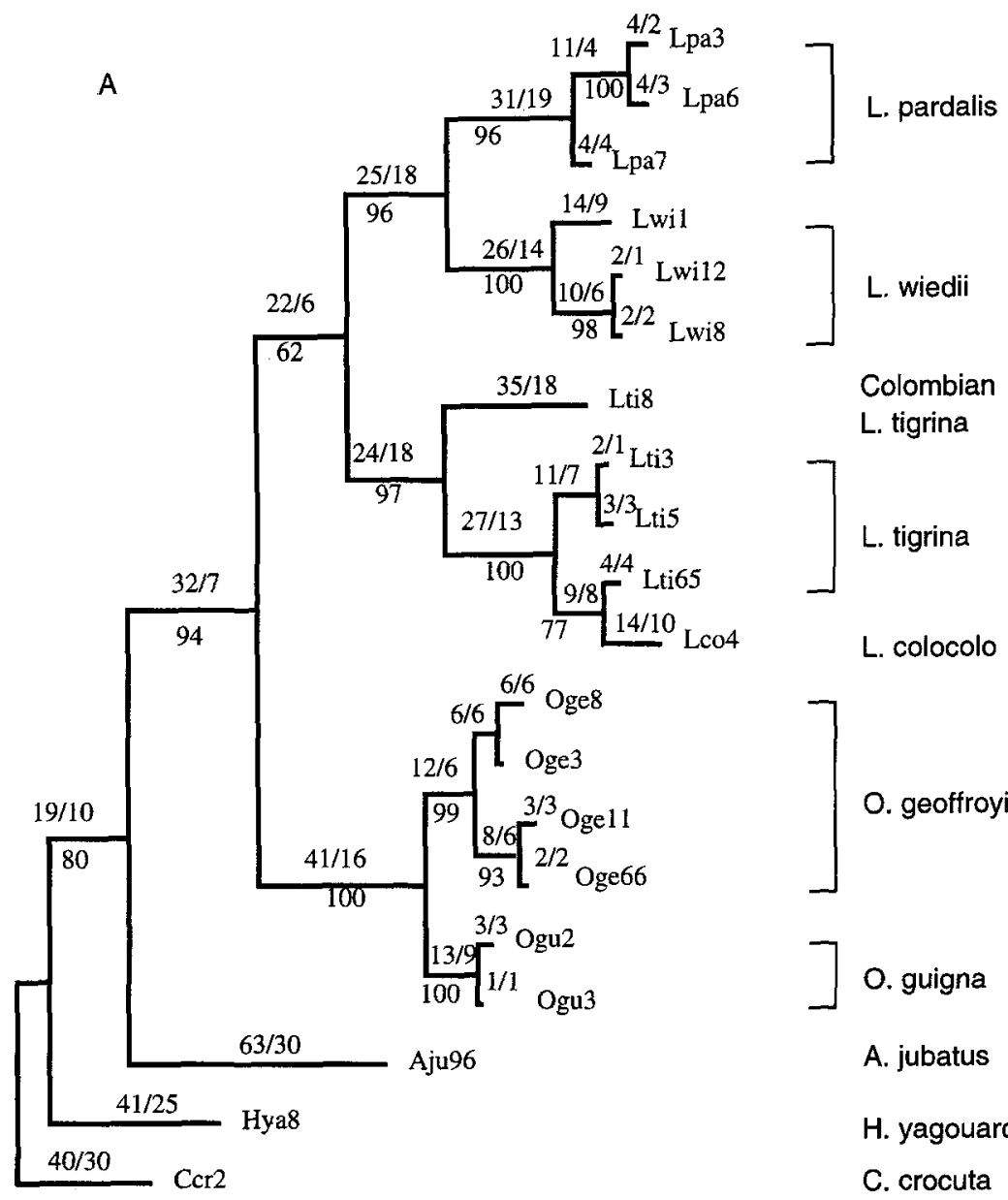
A. jubatus
H. yagouaroundi
C. crocuta

Fig. 2. MtDNA RFLP phylogenetic trees for species of the ocelot lineage. (A) Tree derived from Dollo parsimony algorithm $(N=402$ character states, tree length $=575$ steps, $\mathrm{CI}=0.515)$. Numbers above the branches correspond to the number of steps/number of homoplasies, and numbers below to bootstrap percentages from 100 iterations. (B) Tree derived from minimumevolution method estimated by neighbor-joining algorithm (numbers refer to branch lengths). Time scale represents estimated times of divergence based on fossil calibrations (see text).

strap values ranging from 96 to $100 \%$. The depth of the nodes uniting the two species of each clade differed, suggesting that the ocelot and margay diverged prior to the other two clades. The four tigrina samples separated into two distinct groups: those of Brazilian origin (Lti3, -5, -65) aligned with pampas cat, and an individual of Colombian origin (Lti8) formed an outgroup of the tigrina/pampas cat clade. Genetic divergence ( $p$ $=4.9-5.2 \%$ ) between these two groups of tigrinas was five times greater than among Brazilian tigrina samples $(p=0.2-1.0 \%)$ and comparable to the genetic distance observed between species (Table IV). Depending upon the method used, the relationships among the three groups of ocelot lineage species varied, placing either the ocelot/ 

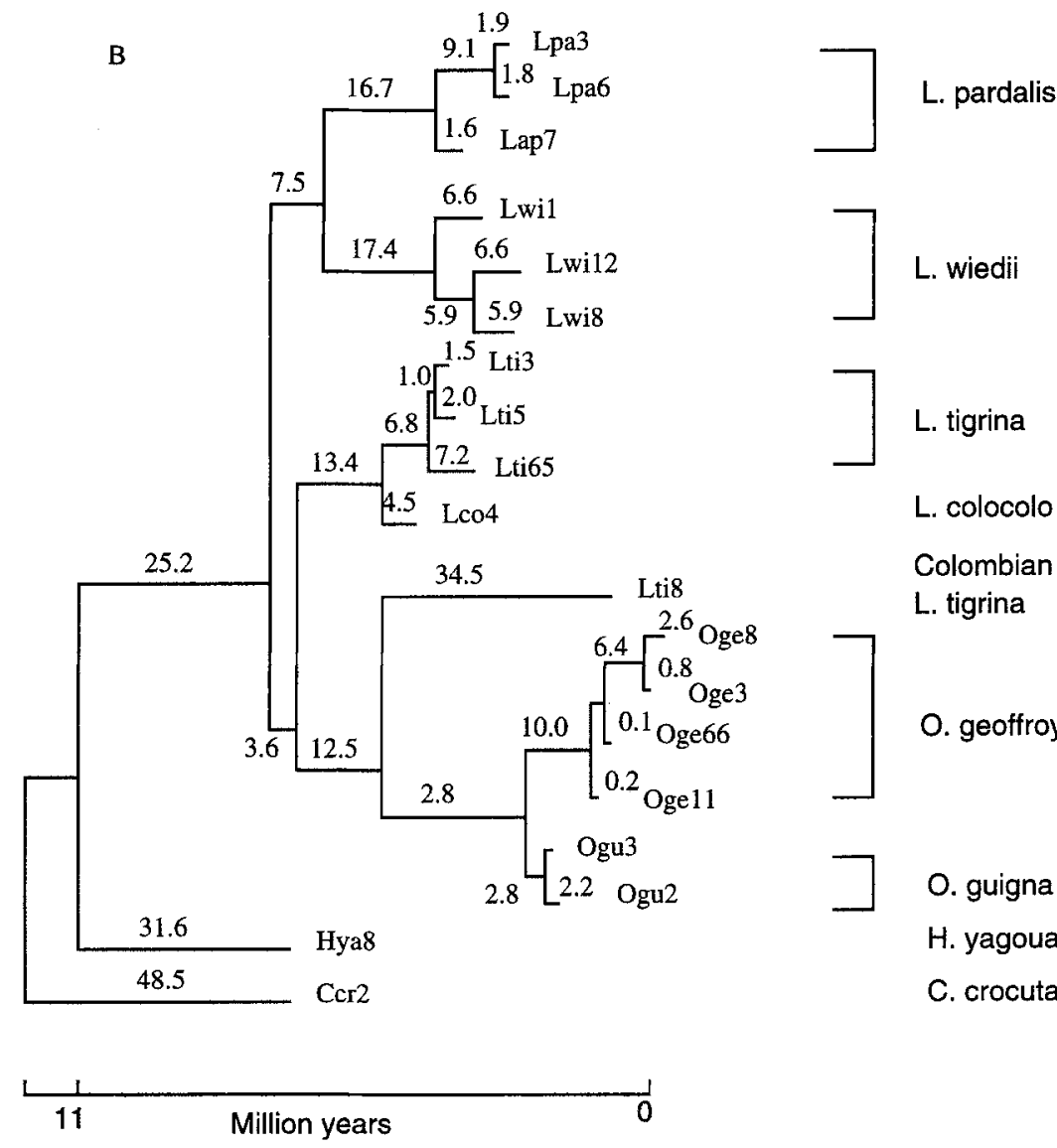

L. tigrina

L. colocolo

Colombian

L. tigrina<smiles>CCCC</smiles>

O. geoffroyi

Fig. 2. Continued.

margay clade (Fig. 2B) or the Geoffroy's cat/kodkod clade (Fig. 2A) as more plesiomorphic. The occurrence of 22 fragment steps ( 16 synapomorphic, 6 homoplastic) aligning the ocelot/margay with the tigrina/pampas cat provides modest parsimony support (bootstrap $=62 \%$ ) favoring an earlier divergence of a Geoffroy's cat/kodkod ancestor.

Mean nucleotide diversity between species of the ocelot lineage and the cheetah (Aju) of the pantherine lineage was $14.12 \%$ (Table IV). Based on the fossil record, the ocelot lineage last shared a common ancestor with cheetah 10-12 MYA (Werdelin, 1985; Wayne et al., 1989). If we assume a constant rate of mitochondrial RFLP change, the rate would be 1.18-1.41\%/MY. Ocelot and margay therefore would have diverged 3.34.0 MYA and the most recent common ancestor among these South American small cats would have occurred 5-6 MYA (Fig. 2B).

\section{Domestic Cat Lineage}

Dollo parsimony and distance-based analysis of domestic cat species produced similar topologies (Fig. 3). Parsimony analysis resulted in three minimum-length trees 
(length $=606$ steps; $\mathrm{CI}=0.584$ ) which differed only in the relationships among the domestic cat and the European and African wild cats. Domestic cat (Fca), European wild cat (Fsi), and African wild cat (Fli) form an unresolved trichotomy, which joined with the sand cat (Fma) by a common ancestor ( $92 \%$ of bootstraps), and represent the most recent radiations within the domestic cat lineage. Jungle cat (Fch) and black-footed cat (Fni) diverged earlier and are less closely related ( $p=5 \%$, compared with approximately $1 \%$ among domestic cat, African wild cat, and European wild cat) (Table V). Jungle cat appeared to diverge prior to black-footed cat in the distance-based analysis but became an unresolved trichotomy in the parsimony analysis with black-footed cat and the sand cat/domestic cat clade. Placement of Pallas cat (Oma) within the domestic cat lineage is weakly supported by maximum-parsimony analysis, which placed Pallas cat within the clade of domestic cats in $70 \%$ of the bootstraps when cheetah and spotted hyena were outgroup species.

The mean variation between species of the domestic cat lineage and the cheetah was $9.00 \%$ (Table V). Assuming that they shared a common ancestor around 8-10 MYA (Wayne et al., 1989), a constant rate of mitochondrial RFLP change is 0.9-1.12\%/MY. Domestic cats/African and European wild cats are estimated to have diverged from sand cats approximately 1.7-2.1 MYA (Fig. 3B).

\section{Pantherine Lineage}

Clouded leopard (Nne) was the most primitive offshoot of the six species in this group. Dollo parsimony analysis produced two equally parsimonious minimum-length trees of length 623 steps $(\mathrm{CI}=0.587$ ) (Fig. 4A). These trees supported the association of tiger (Pti) and snow leopard (Pun) (bootstrap proportion $=70 \%$ ), but the relationship of leopard (Ppa) and lion ( $\mathrm{Ple}$ ) was more weakly supported (bootstrap proportion = $55 \%)$. Minimum-evolution analysis using the neighbor-joining algorithm also implicated the lion/leopard and tiger/snow leopard as monophyletic groups (Fig. 4B).

Mean variation among species of the Panthera genus (including clouded leopard) and the cheetah was $15.32 \%$ (Table VI). Assuming that they shared a common ancestor with cheetah 3.5-4.5 MYA (Ficcarelli, 1984; Turner, 1987), their rate of mitochondrial RFLP change was $3.40-4.37 \% / M Y$. Lions and leopards therefore would have shared a common ancestor 2.0 MYA, while the date of the Panthera common ancestor is approximately 3.0 MYA (Fig. 4).

\section{DISCUSSION}

Phylogenetic analysis of mtDNA variation within the three major clades of Felidae corroborated their different patterns of evolutionary history. Members of the ocelot lineage are distantly related to the other felid species but diverged in a relatively short time into several lineages. In contrast, species of the domestic cat lineage separated from the other felids more recently and, with the exception of the domestic cat/European and African wild cat group, are separated from each other by longer branch lengths. Members of the Panthera genus are closely interrelated, suggestive of recent and rapid speciation.

Within the ocelot lineage, our results concur with the results of two-dimensional 

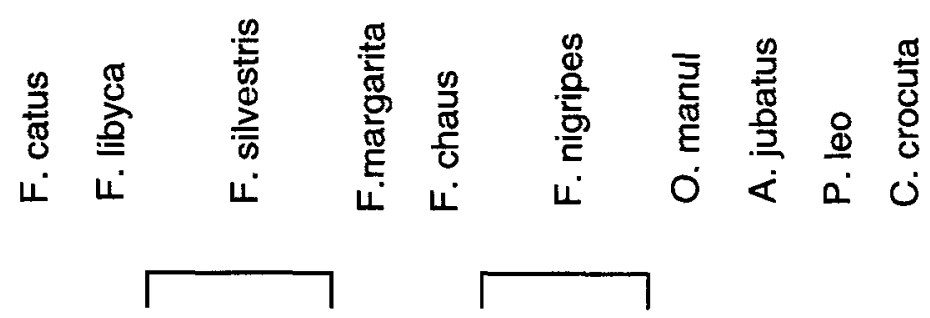

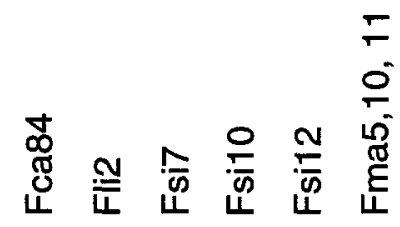

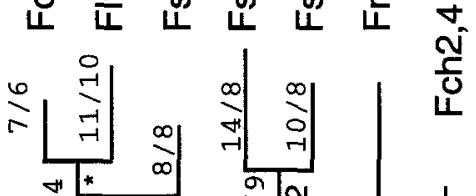

भा

\begin{tabular}{l|l}
0 \\
0 \\
7
\end{tabular}
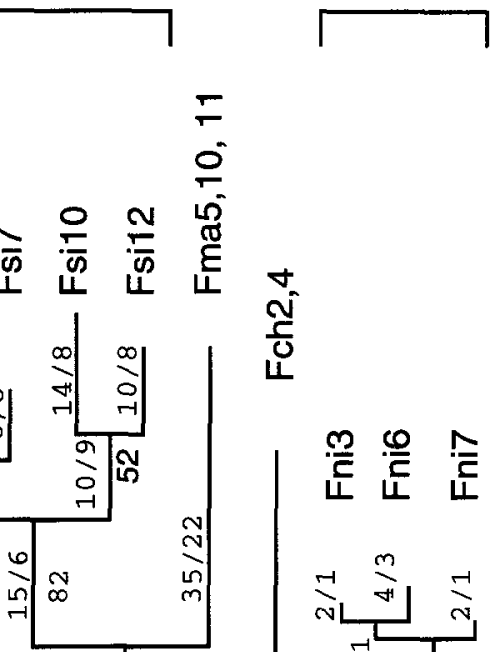

$\stackrel{m}{\frac{m}{L}} \stackrel{\frac{0}{L}}{\frac{1}{L}}$

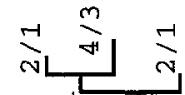

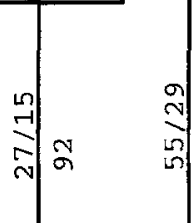

i

i

$\varangle$

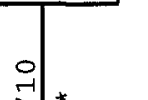

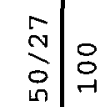

ฏิ

กิ

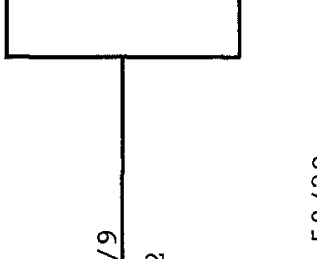

กิก ส

ஸे

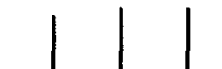




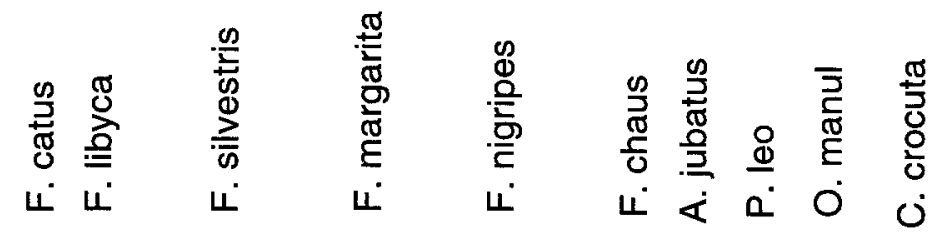

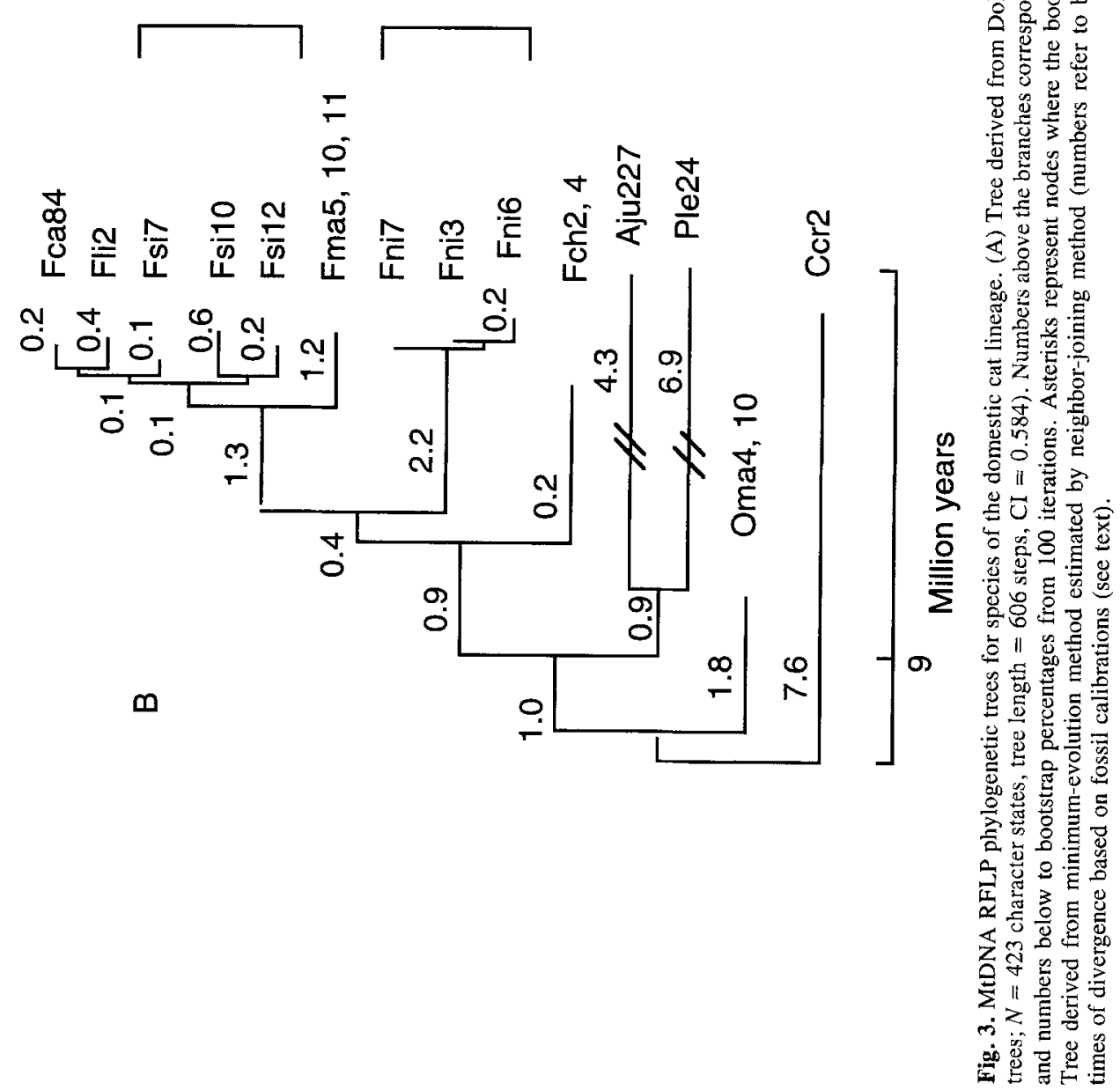



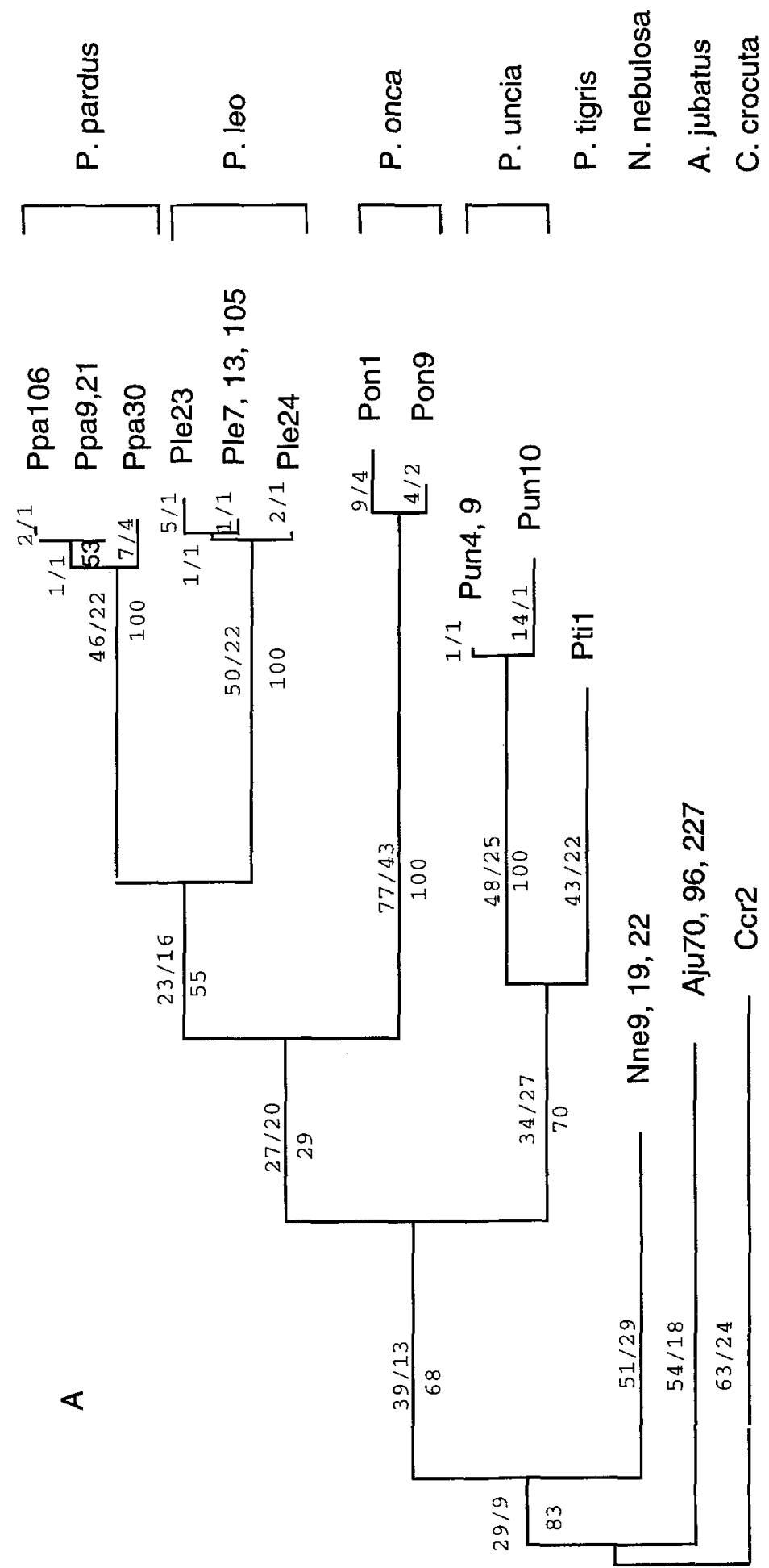


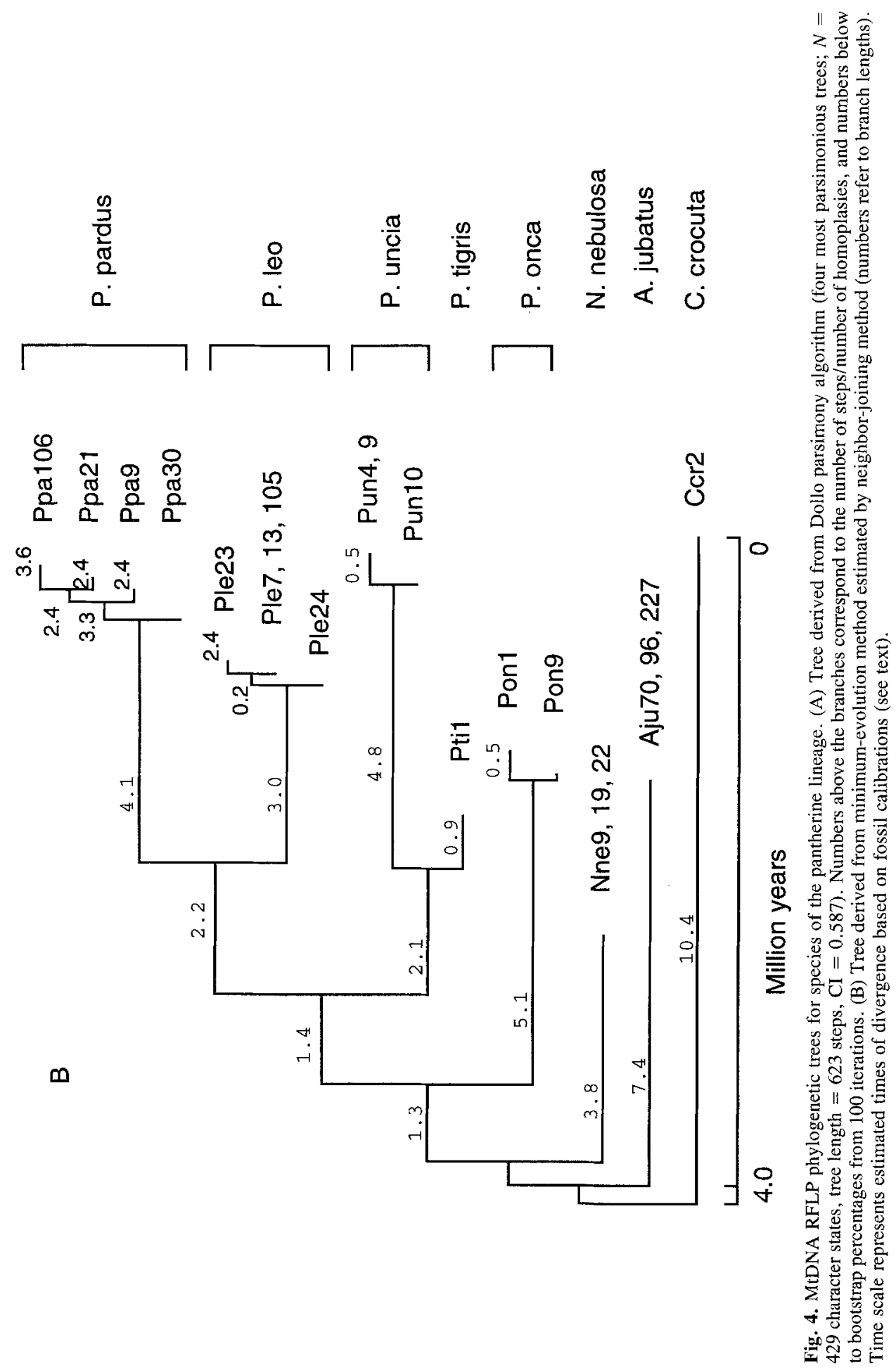


protein electrophoresis and allozyme analyses, which combine ocelot and margay into a separate clade and affiliate Geoffroy's cat with kodkod (Pecon Slattery et al., 1994). However, the relationships among tigrina, pampas cat, and the other four species differ between the protein electrophoretic methods and the RFLP analysis. This difference in topology may be the result of sampling because the present data suggest that there may be two divergent phylogenetic clades of tigrina, one made up of individuals from Brazil and the other, more divergent clade, composed of individuals from Colombia. Colombian tigrina samples were not available for the protein analyses (Pecon Slattery et al., 1994).

Morphological evidence provides limited support for these results. The close relam tionship between ocelot and margay has invariably been supported by morphological studies (Glass and Martin, 1978; Salles, 1992). Further, ocelot and margay also share a unique deletion of chromosome D2 (Modi and O'Brien, 1988). There has been little agreement, however, as to the relationships among the other species of the lineage (Hemmer, 1978; Herrington, 1986; Salles, 1992).

Divergence dates within the ocelot lineage estimated from RFLP data are consistent with those calculated from the two-dimensional electrophoretic data. Both estimates suggest that ocelot species diverged initially around 6 MYA, and differentiated further 2-5 MYA. The timing of this radiation coincides with the formation of the land bridge between North and South America, before which there were no eutherian mammal carnivores (including cats) in South America (Martin, 1989; Wayne et al., 1991). This chronology is also fairly consistent with the fossil record. The earliest predecessors of the ocelots ( $F$. lacustris or $F$. rexrodenosis) appeared 4-5 MYA. Fossils of modern Leopardus species date to approximately 1.5-2.5 MYA in North America and 0.3-0.4 MYA in South America (Berta, 1983).

The evolutionary history of the domestic cat lineage produces a topology which is described fairly consistently by the genetic methods employed to date (Collier and O'Brien, 1985; Modi and O'Brien, 1988; Lopez et al., 1994). Both 12S rRNA sequences (Lopez et al., 1994) and mtDNA RFLP determine that the most distantly related species of the lineage is the Pallas cat (about 6 MYA), which also differs from the other species by a chromosomal inversion (Wurster-Hill and Centerwall, 1982) and the absence of endogenous RD114 retroviral sequences (Benveniste, 1985). The second group to emerge is the jungle cat and the black-footed cat, which diverged prior to other Felis species, although the available data conflict as to whether the jungle cat or black-footed cat diverged first. The mtDNA RFLP data give conflicting results depending on the method of analysis (Fig. 3). Concurrent studies examining mtDNA sequence data have also been unable to resolve these interrelationships. Sequences of mtDNA $12 \mathrm{~S}$ rRNA favor the jungle cat as diverging first, while cytochrome $b$ sequences favor the black-footed cat as being earlier (Masuda et al., 1996). Perhaps a stronger character to consider would be the presence of Numt in the jungle cat but not in the black-footed cat. If this remarkable nuclear transposition and amplification of the mtDNA genome were considered as a principal and unique evolutionary event, it would suggest that the black-footed cat lineage was likely a more primitive divergence than the other Felis species.

MtDNA RFLP data appear to resolve the most recent domestic cat radiation, placing the sand cat as a plesiomorphous outgroup of domestic and European and African wild cats (1.6 MYA). The earliest fossil record from this lineage, of Felis lunensis 
(3 MYA), does not contradict our findings, but fossil evidence for this lineage is generally sparse (Kurtén, 1965). There has been little consistency among the results of different morphological studies on the domestic cat lineage, except often to align closely European wild cat and African wild cat (Randi and Ragni, 1991) and to distinguish Pallas cat from the rest of the lineage (Hemmer, 1978; Herrington, 1986; Salles, 1992). The composite results of morphology, cytology, 12S rRNA sequences, cytochrome $b$ sequences, and mtDNA RFLP analyses affirm the suggestion that European wild cat and African wild cat be subsumed under the same species name, Felis silvestris, in agreement with Wozencraft (1993).

Relationships among species of the Panthera genus, which evolved recently and rapidly, are difficult to resolve with the genetic methods applied thus far (O'Brien et al., 1987). This may be due in part to transmission of substantive ancestral genetic polymorphisms (Wu, 1991) common to recent monophyletic radiations that retain ancestral genetic variation. Within the Panthera genus the mtDNA RFLP data indicate a recent relationship between tiger and snow leopard. This finding differs from the results of Janczewski et al. (1995), who found no support for aligning tiger with snow leopard from analysis of cytochrome $b$ and $12 \mathrm{~S}$ rRNA sequences but, instead, suggested that tiger and clouded leopard may be sister taxa. However, their results, especially with $12 \mathrm{~S}$ rRNA, suggested that there was a common ancestry between lion and leopard (2.0 MYA), a result weakly implied by the restriction-site analysis (Fig. 4). A close relationship between lion and leopard also has been suggested by several morphological studies (Hemmer, 1978; Herrington, 1986; Salles, 1992), as has the affinity between tiger and snow leopard (Hemmer, 1978; Herrington, 1986).

The timing of divergence of the nodes within the Panthera genus is consistent with fossil evidence. The earliest lion fossils date between 1 and 2 MY (Neff, 1982) and leopard fossils date 3.0 MY from the mid-Pliocene (Savage and Russell, 1983; Turner, 1987), within the range of the suggested divergence between the two species of $2.0 \mathrm{MY}$. The existence of 1.8-MY-old tiger-like fossils (Neff, 1982) suggests, however, that the divergence of tigers may have been somewhat earlier than our 1.5-MY estimate between snow leopard and tiger.

\section{Rates of mtDNA Divergence}

The rates of base-pair change within the lineages, calculated from when each lineage was estimated last to share a common ancestor with the cheetah, ranged from $1.0 \% / \mathrm{MY}$ for the domestic cat lineage to $3.8 \% / \mathrm{MY}$ for the Panthera genus. These are within the range of values commonly cited for mitochondrial evolution (Brown, 1985; Martin et al., 1992; Martin and Palumbi, 1993). Although these values represent a relatively large amount of variation within the same family, they should be interpreted with caution. Although significant mtDNA rate heterogeneities have been shown across lineages of Hawaiian Drosophila (DeSalle and Templeton, 1988) and turtles (Avise et al., 1992), the cause of these differences is unclear. One possibility is that the mtDNA haplotype date could be later than the actual ancestral population if mtDNA diversity has been lost during evolution (Wolpoff, 1989). The probability that diversity is lost is higher in small, nonexpanding populations (Avise et al., 1984).

These rate estimates for Felidae should also be used cautiously since calibrations 
from the felid fossil record are poor and because mtDNA variation tends to decelerate after $8 \%$ divergence (Moritz et al., 1987). This deceleration in divergence rate is apparent when comparing the index of proportion of shared mitochondrial restriction fragments of spotted hyena (Ccr) and cheetah with other felid species (Tables IV-VI). Although spotted hyena last shared a common ancestor with felids about 38.5 MYA (Hunt, 1989), the mean divergence between hyena and Felidae species was similar to those among more distantly related cat species (with divergences less than $12 \mathrm{MYA}$ ). For example, the mean divergence between hyena and ocelot lineage species was $10.7 \%$ (compared with $14.2 \%$ between cheetah and ocelot lineage species), $12.1 \%$ between hyena and domestic cat lineage species (compared with $9.0 \%$ ), and $16.8 \%$ between hyena and pantherine lineage species (compared with $14.2 \%$ ).

The phylogenetic relationships and genetic patterns discerned from mtDNA RFLP should be confirmed with other mitochondrial and nuclear genes, because relationships determined from mtDNA data may not always conform with true species phylogenies, particularly within recent mammal radiations such as occurred among Felidae species (Cronin, 1991). The apparent large differences in interspecific variation among felid species also merit further study to determine their cause.

\section{ACKNOWLEDGMENTS}

We appreciate the assistance of Robyn Hottman in data collection and the advice of M. Culver, J. Lopez, J. Pecon Slattery, and C. Stephens in the analysis and in the review of early versions of the manuscript. We are grateful to the numerous people who helped obtain blood and tissue samples for this study and to the institutions and individuals listed in Table I who provided access to their animals. All tissue samples were collected in full compliance with specific Federal Fish and Wildlife permits [Convention on International Trade in Endangered Species of Wild Fauna and Flora (CITES); Endangered and Threatened Species] issued to the National Cancer Institute, National Institutes of Health (principal officer, S. J. O'Brien), by the U.S. Fish and Wildlife Service of the Department of the Interior.

\section{LITERATURE CITED}

Avise, J. C. (1991). Ten unorthodox perspectives on evolution prompted by comparative population genetic findings on mitochondrial DNA. Annu. Rev. Genet. 25: 45-69.

Avise, J. C. (1994). Molecular Markers, Natural History and Evolution, Chapman and Hall, New York.

Avise, J. C., Neigel, J. E., and Arnold, J. (1984). Demographic influences of mitochondrial DNA lineage survivorship in animal populations. J. Mol. Evol. 20: 99-105.

Avise, J. C., Arnold, J., Ball, R.M., Bermingham, E., Lamb, T., Neigel, J. E., Reeb, C. A., and Saunders, N. C. (1987). Intraspecific phylogeography: The mitochondrial DNA bridge between population genetics and systematics. Annu. Rev. Ecol. Syst. 18: 489-522.

Avise, J. C., Bowen, B. W., Lamb, T., Meylan, A. B., and Bermingham, E. (1992). Mitochondrial DNA evolution at a turtle's pace: Evidence for low genetic variability and reduced microevolutionary rate in the Testudines. Mol. Biol. Evol. 9: 457-473.

Benveniste, R. E. (1985). The contributions of retroviruses to the study of mammalian evolution. In: Molecular Evolutionary Genetics, R. J. Macintyre, ed., pp. 359-417, Plenum Press, New York.

Benveniste, R. E., and Todaro, G. J. (1974). Evolution of C-type viral genes: Inheritance of exogenously acquired viral genes. Nature 252: 456-459.

Benveniste, R. E., Sherr, C. J., and Todaro, G. J. (1975). Evolution of type C viral genes: Origin of feline leukemia virus. Science 190: $886-888$. 
Berta, A. (1983). A new species of small cat (Felidae) from the late Pliocene-early Pleistocene Uquian of Argentina. J. Mammal. 64: 720-725.

Brown, W. M. (1985). The mitochondrial genome of animals. In: Molecular Evolutionary Genetics, R. J. MacIntyre, ed., pp. 95-130, Plenum Press, New York.

Collier, G. E., and O'Brien, S. J. (1985). A molecular phylogeny of the Felidae: Immunological distance. Evolution 39: 473-487.

Cronin, M. A. (1991). Mitochondrial-DNA phylogeny of deer (Cervidae). J. Mammal. 72: 553-566.

DeBry, R. W., and Slade, N. A. (1985). Cladistic analysis of restiction endonuclease cleavage maps within a maximum-likelihood framework. Syst. Zool. 34: 21-34.

DeSalle, R., and Templeton, A. R. (1988). Founder effects and the rate of mitochondrial DNA evolution in Hawaiian Drosophila. Evolution 42: 1076-1084.

Ewer, R. F. (1973). The Carnivores, Comell University Press, Ithaca, NY.

Farris, J. S. (1977). Phylogenetic analysis under Dollo's law. Syst. Zool. 26: 77-88.

Felsenstein, J. (1993). PHYLIP, Phylogeny Inference Package (Version 3.5), University of Washington, Seattle.

Ficcarelli, G. (1984). The Villafranchian cheetahs fron Tuscany and remarks on the dispersal and evolution of the genus Acinonyx. Palaeontogr. Italica 73: 94-103.

Glass, G. E., and Martin, L. D. (1978). A multivariate comparison of some extant and fossil Felidae. Carnivore 1: 80-87.

Guggisberg, C. A. W. (ed.) (1975). Wild Cats of the World, Taplinger, New York.

Hemmer, H. (1978). The evolutionary systematics of living Felidae: Present status and current problems. Carnivore 1: 71-78.

Herrington, S. J. (1986). Phylogenetic Relationships of the Wild Cats of the World, Ph.D. dissertation, University of Kansas, Lawrence.

Hunt, R. M. (1989). Evolution of the aeluroid Carnivora: Significance of the ventral promontorial process of the petrosal, and the origin of basicranial patterns in the living families. Am. Mus. Novit. 2930: 1-32.

Janczewski, D. N., Modi, W. S., Stephens, J. C., and O'Brien, S. J. (1995). Molecular evolution of mitochondrial $12 \mathrm{~S}$ RNA and cytochrome b sequences in the pantherine lineage of Felidae. Mol. Biol. Evol. 12: 690-707.

Kurtén, B. (1965). On the evolution of the European wild cat, Felis silvestres Schreber. Acta Zool. Fennica 111: $1-29$.

Lopez, J. V., Yuhki, N., Mastuda, R., Modi, W., and O'Brien, S. I. (1994). Numi, a recent transfer and tandem amplification of mitochondrial DNA to the nuclear genome of the domestic cat. J. Mol. Evol. 39: 174-190.

Lopez, J. V., Cevario, S., and O'Rrien, S. J. (1996). Complete nucleotide sequences of the domestic cat (Felis catus) mitochondrial genome and a transposed mtDNA tandem repeat (Numt) in the nuclear genome. Genomics 33: 229-246.

Martin, A. P., and Palumbi, S. R. (1993). Body size, metabolic rate, generation time, and the molecular clock. Proc. Natl. Acad. Sci. USA 90: 4087-4091.

Martin, A. P., Naylor, G. J. P., and Palumbi, S. R. (1992). Rates of mitochondrial DNA evolution in sharks are slow compared with mammals. Nature 357: 153-155.

Martin, L. D. (1989). Fossil history of the terrestrial Carnivora. In: Carnivore Behavior, Ecology and Evolution, J. L. Gittleman, ed., pp. 536-568, Cornell University Press, Ithaca, NY.

Masuda, R., Lopez, J. V., Pecon Slattery, J., Yuhki, N., and O’Brien, S. J. (1996). Molecular phylogeny of mitochondrial 12s rRNA and cytochrome $b$ sequences in the Felidae: Ocelot and domestic cat lineages. Mol. Phylo, Evol. (in press).

Menotti-Raymond, M., and O'Brien, S. J. (1993). Dating the genetic bottleneck of the African cheetah. Proc. Natl. Acad. Sci. USA 90: 3172-3176.

Miththapala, S., Seidensticker, J., and O'Brien, S. J. (1996). Phylogeographic subspecies recognition in the leopards (Panthera pardus): Molecular genetic variation. Conserv. Biol. (in press).

Modi, W. S., and O'Brien, S. J. (1988). Quantitative cladistic analysis of chromosomal banding among species in three orders of mammals: Hominoid primates, felids and arvicolid rodents. In: Chromosome Structure and Function, J. P. Gustafson and R. Appels, eds., pp. 215-242, Plenum Press, New York.

Modi, W. S., Nash, W. G., Ferrari, A. C., and O'Brien, S. J. (1987). Cytogenetic methodologies for gene mapping and comparative analyses in mammalian cell culture systems. Gene Anal. Tech. 4: 75-85.

Moritz, C., Dowling, T. E., and Brown, W. M. (1987). Evolution of animal mitochondrial DNA: Relevance for population biology and systematics. Annu. Rev. Ecol. Syst. 18: 269-292.

Neff, N. A. (1982). The Big Cats: The Paintings of Guy Coheleach, Abrams, New York.

Nei, M., and Li, W. H. (1979). Mathematical model for studying genetic variation in terms of restriction endonucleases. Proc. Natl. Acad. Sci. USA 76: 5269-5273.

Nei, M., and Tajima, F. (1985). Evolutionary change of restriction cleavage sites and phylogenetic inference for man and apes. Mol. Biol. Evol. 2: 189-205. 
O'Brien, S. J. (1986). Molecular genetics in the domestic cat and its relatives. Trends Genet. 2: 137-142.

O'Brien, S. J. (1994a). Genetic and phylogenetic analyses of endangered species. Annu. Rev. Genet. 28: 467489.

O'Brien, S. J. (1994b). A role for molecular genetics in biological conservation. Proc. Natl. Acad. Sci. USA 91: 5748-5755.

O'Brien, S. J., Collier, G. E., Benveniste, R. E., Nash, W. G., Newman, A. K., Simonson, J. M., Eichelberger, M. A., Seal, U. S., Bush, M., and Wildt, D. E. (1987). Setting the molecular clock in Felidae: The great cats, Panthera. In: Tigers of the World, R. L. Tilson, ed., pp. 10-27, Noyes, Park Ridge, NJ.

O'Brien, S. J., Roelke, M. E., Yuhki, N., Richards, K. W., Johnson, W. E., Franklin, W. L., Anderson, A. E., Bass, O. L., Jr., Belden, R. C., and Martenson, J. S. (1990). Genetic introgression within the Florida panther Felis concolor coryi. Natl. Geogr. Res. 6: 485-494.

O'Brien, S. J., Martenson, J. S., Johnson, W. E., Miththapala, S., Janczewski, D. N., Pecon Slattery, J., Gilbert, D. A., Packer, C., Roelke, M. E., Bush, M., and Wildt, D. E. (1996). Conservation genetics of the Felidae: In: Conservation Genetics of Rare and Endangered Species, J. C. Avise and J. Hamrick, eds., pp. 50-74, Chapman and Hall, NY.

Pecon Slattery, J., Johnson, W. E., Goldman, D., O'Brien, S. J. (1994). Phylogenetic reconstruction of South American felids defined by protein electrophoresis. J. Mol. Evol. 39: 296-305.

Randi, E., and Ragni, B. (1991). Genetic variability and biochemical systematics of domestic and wild cat populations (Felis silvestris: Felidae). J. Mammal. 72: 79-88.

Reeves, R. H., and O'Brien, S. J. (1984). Molecular genetic characterization of the RD-114 gene family of endogenous feline retroviral sequences. $J$. Virol. 52: 164-171.

Salles, L. O. (1992). Felid phylogenetics: Extant taxa and skull morphology (Felidae, Aeluroidea). Am. Mus. Novit. 3047: 1-67.

Sambrook, J., Fritsch, E. F., and Maniatis, T. (1989). Molecular Cloning, a Laboratory Manual, 2nd ed., Cold Spring Harbor Laboratory Press, Cold Spring Harbor, NY.

Savage, D. E., and Russell, D. E. (1983). Mammalian Paleofaunas of the World, Addison-Wesley, London.

Seidensticker, J., and Lumpkin, S. (eds.) (1991). Great Cats: Majestic Creatures of the Wild, Weldon Owen, Sydney, Australia.

Swofford, D. L. (1993). PAUP: Phylogenetic Analysis Using Parsimony, Version 3.1.1, Computer program, Smithsonian Institute, Washington, DC.

Templeton, A. R. (1983). Phylogenetic inference from restriction endonuclease cleavage site maps with particular reference to the evolution of humans and the apes. Evolution 37: 221-244.

Turner, A. (1987). New fossil carnivore remains from the Sterkfontein hominid site (Mammalia: Camivora). Ann. Transvaal. Mus. 34: 319-347.

Wayne, R. K., Benveniste, R. E., Janczewski, D. N., and O’Brien, S. J. (1989). Molecular and biochemical evolution of the Carnivora. In: Carnivore Behavior, Ecology and Evolution, J. L. Gittleman, ed., pp. 465-494, Cornell University Press, Ithaca, NY.

Wayne, R. K., Van Valkenburgh, B., and O'Brien, S. J. (1991). Molecular distance and divergence time in carnivores and primates. Mol. Biol. Evol. 8: 297-319.

Werderlin, L, (1985). Small Pleistocene felines of North America. J. Vert. Paleo. 5: 194-210.

Wilson, A. C., Cann, R. L., Carr, S. M., George, M., Gyllensten, U. B., Helm-Bychowski, K. M., Higuchi, R. G., Palumbi, S. R., Prager, E. M., Sage, R. D., and Stoneking, M. (1985). Mitochondrial DNA and two perspectives on evolutionary genetics. Biol. J. Linn. Soc. 26: 375-400.

Wolpoff, M. (1989). Multiregional evolution: The fossil alternative to Eden. In: The Human Revolution: Behavioural and Biological Perspectives on the Origins of Modern Humans, P. Mellars and C. Stringer eds., pp. 62-108, Princeton University Press, Princeton, NJ.

Wozencraft, M. (1993). Order Carnivora: In: Mammal Species of the World, 2nd ed., D. E. Wilson, and D. M. Reeder, eds., pp. 279-348, Smithsonian Institution Press, Washington, DC.

Wu, C.-I. (1991). Inferences of species phylogeny in relation to segregation of ancient polymorphisms. Genetics 127: 429-435.

Wurster-Hill, D. H., and Centerwall, W. R. (1982). The interrelationships of chromosome banding patterns in canids, mustelids, hyena, and felids. Cytogenet. Cell Genet. 15: 306-331. 